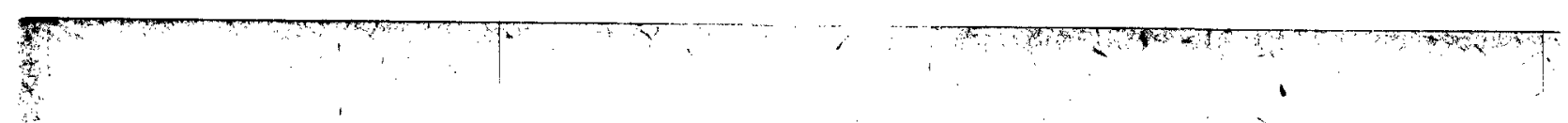

348

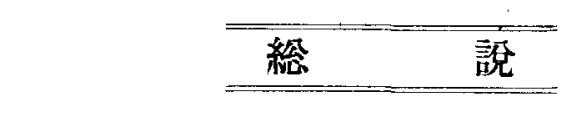

無声放電と化学 反応 (II)

鈴 木 桃 太 郎

(防衛店防衛大学校)

\section{3. 無声放電における電流}

無声放電に於て流れる電流が少くす2つの部分より成 る事は，既に Warburgによつて認められ，更にとの才 ッシログムラが Klemenc によつて得られた事は前節に 述べた通りである. Klemenc 等によればこの 2 つ 1つは通常オゾン管に流れる電流即ら低周波電流であ り，その周波数はオゾン管に供給される電源電圧の周波 数 $(50$ 㕛は $60 \mathrm{c} / \mathrm{s})$ 等しい. 它 51 つの電流は高周 波電流であり，その周波数の値は大約 $10^{4} \sim 10^{5} \mathrm{c} / \mathrm{s}$ で ある. Warburg の值はこれより更に一桁低いが，著者

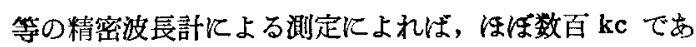
り, Klemenc の值に近い。すつともこの周波数は，回 路の時間定数にも左右されるるのであるが，通常用いら れる定型的な実験装置では $10^{2} \mathrm{kc}$ の程度である。この 外に波長計に感ぜられる波長としては，I, 第6図の才

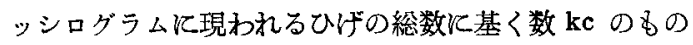
があるが，化学反応的には 2 次的のものである.

さてこの $10^{2} \mathrm{kc}$ の高周波電流は変位電流であり, 徒つ て化学反応には全然関係せず，化学反応を支配するもの は低周波電流の值であららとい5のが Klemenc 等の考 えであるが(1)，実測の結果はや〉これと異るものがある。 例えば，水素に少量の酸素を混して，これに $50 \mathrm{c} / \mathrm{s}$ 交 流による無声放電を行わせると, 過酸化水素を得ること ができる.この際酸素の濃度を变えてこれに対応する過 酸化水素の收量, 低周波電流, 高周波電流を測定したも のが, 第 1 図 A,Bである(2). Aは2つの放電々厌につ いて求めた側定值で，2つの曲線は共侄酸素 $3.5 \% の$ 混合率の附近に過酸化水素の収量の最低值がある。一方 BKついて見ると，低周波電流（図の L.Fとある方）は 酸素 $3.5 \%$ 最高值を有し, 高周波電流 (図の H.F とあ る方）恃同し所㳊最值がある。言葉を換えると化学反 応の有様と平行的な関係隹あるのは, 高周波電流であっ て, 低周波電流ではない。この事実は, 過酸化水素生成 反応に影響を与えているものはむしろ高周波電流であつ て，基礎の低周波電流てはないことがわかる。

同じような事実はオゾン生成反応忆も見られるのであ つて, 印加電圧の相当広い範用に亘つて, 無声放電によ

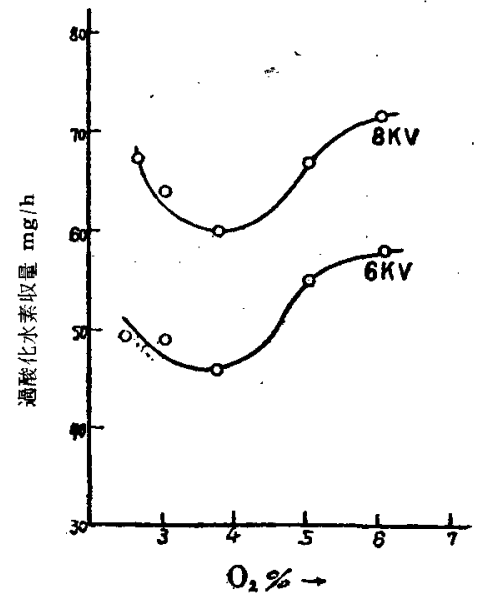

A

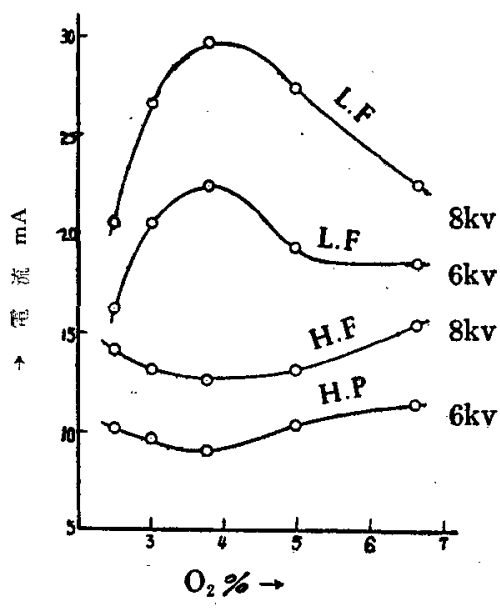

B

第 1 図 過酸化水素の収量と電流との関係

つて生じたオゾンの量は $20 \mathrm{kc}$ 以上の高周波電流との間 に直線関係を有している。

．以上の事実加見ても，無声放電に伴 5 化学反応飞於 てより多くの関連を有するものは，高周波電流でする よ5に兒える。従つて無声放電の察に流れる電流をる5 少し詳しく㯝べる必要である。 
先ず無声放電の回路は 1 つの振動回路と考える事が出 来る. 放電管自体す 3 つの蓄電器, 即らガラス肉の 20 の蓄電器及びその間に挾まれる空気蓄電器が直列に連結 せられている・ガラス面の電圧が或值まで上り放電がお きると, 中央の空気蓄電器は短絡せられ,電荷の移動が起 る・これが衝撃電流であり，オッシログラムの上にひげ として現われるるのである.この墅撃電流の振動数は圆 路の電気的時間定数にる関係している.この高周波振動 は前にも一寸触れたように減衰的なるので(第 2 図), 数 周期で衰減し去る，この電気振動は勿論放電空間部即ら 反応空間でる起つて特るのであるから，それが反応に何 等かの影響を与劣るであるうことは，当然考えられるこ とである。この点に関する理論的な考察は未だ充分なる のとはいえないが，実験的には多くの放電反応に於て周 波数を増寸事が,反応に有利である事が知られている(3). 例总ば堂素をアークによつて酸化する反応の如きはそれ でる、従つて無声放電に淤ける化学反応は, 無声放電 に伴つて起る高周波振動電流に大きく影響されるである 万事は, 充分想像出来る.

さて次とひげの 1 本 1 本, 即ち衝撃電流の本体を見極 める方法として，放電の 1 極又は両極の写真乾板として 無声放電を行わしめ，ここに流れる電流をオッシログラ ムに取る実験が行われた(4). 装置は第3図に示す通り で，放電装置には板状放電管を用い，一極は通常の硝子 板，他方又は双方を写真乾板とし，これを気密容器の中 に入れる. 容器内には種々の気体が送入出来る. 第 4 図 に示された全装置の回路図からも知られるように放電管 には高い直流電圧をかけ，ごく短い時間だけ放電を行わ せる. 同時に同期スイッチを用いて，この放電のひげを オッシログラムに撮影して双方を比較する。ここに挙け

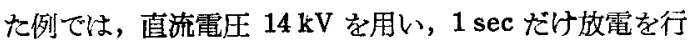
わしめた。放電管の空間々隙は 3 種 $(0.5,0.9,1.2 \mathrm{~mm})$ のものが用いられた・放電管の両極共写顀乾板を用い て, 無声放電を行わしめこれを現像すると, 両方の極板

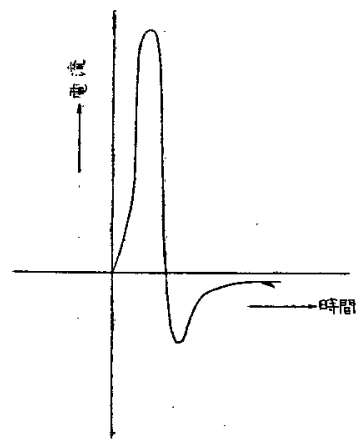

第 2 図 減衰する高周波振動 $\left(\begin{array}{l}\text { 下の部分のない1回 } \\ \text { だけの場合もある }\end{array}\right)$

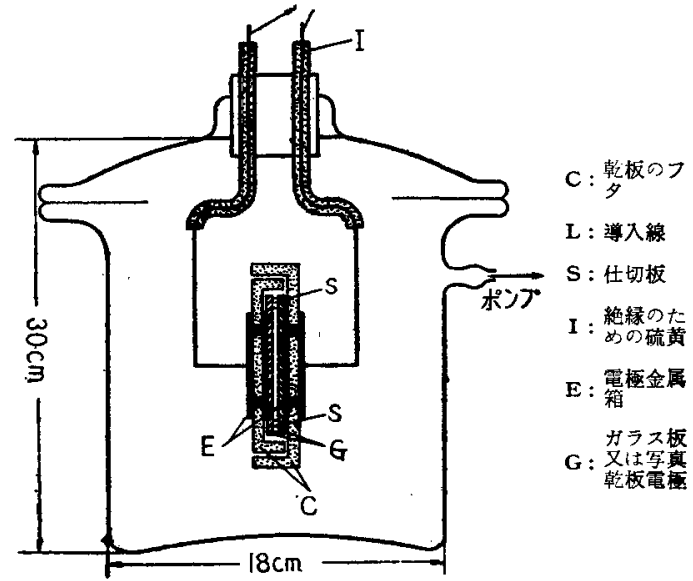

第 3 図 無声放電の撮影䒾置

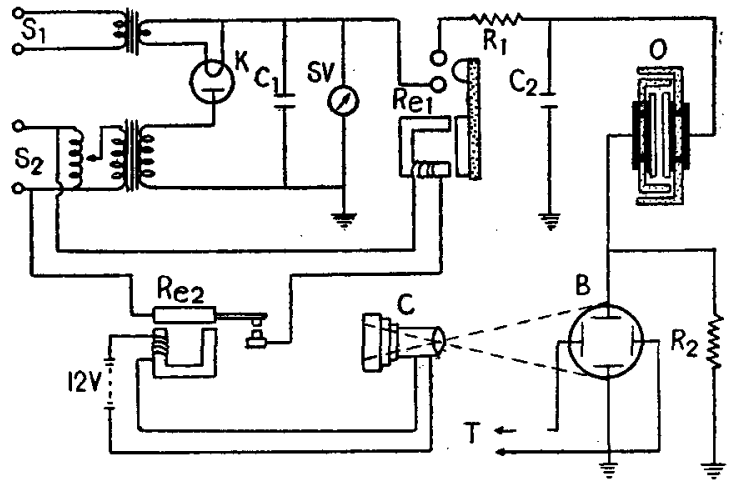

K: ケノトロン KX-135

$\mathrm{S}_{1}$ : 交流電源 $50 \mathrm{c} / \mathrm{s} 100 \mathrm{~V}$

O：烣䉓管

$\mathbf{R e}_{1}$ : 高压リレー

C: 为友

$\mathbf{R}_{1}: 46 \mathrm{M} \Omega, \mathbf{R}_{2}: 1 \mathrm{M} \Omega$

第 4 図装置の回路㘡
SV: 静電々压阡

$\mathrm{S}_{2}:$ 父流電源 $50 \mathrm{c} / \mathrm{s} 200 \mathrm{~V}$

B：ブラウン管

$\mathrm{Re}_{2}$ 低压りレー

$T: 150 \mathrm{c} / \mathrm{s}$ 鋸崡状波発生装置

$\mathrm{C}_{1}: 3 \mu \mathrm{F}, \mathrm{C}_{2}: 0.003 \mu \mathrm{F}$
の上にはめばたの様な点が一面に現われる・その散布状 態は両極上す全く同一で，完全に重祦合わ世る事が出来 る.しかし個々の点の形を両極板について比較すると， その形はかなり台がつている。即ち陽極上の点はほな゙ さの等しい円であるが，陰極上の点は星状で，いわゆる Lichtenbergの図形似ている。第 5 図に陰極上の点の 一例を揭げた.オッシロダラムの一例を第 6 図に示し た.これは第 5 図の散布点の写真に対応するるので,下 方の太い帯は直流の基礎波で，その上に衙撃電流を示す ひ活が現われている、第 4 図の回路図からも分るように 掃引は $150 \mathrm{c} / \mathrm{s}$ 鉛因状波で行つているから，このひげは 150 回反稪往復して揥引されたるのである. 回路の定数 を適当にきる事によつて，1本のひげの長さは，それ に相当する衝撃電流によつて運に゙れた電荷の值に此例す るように調整する事ができる。 


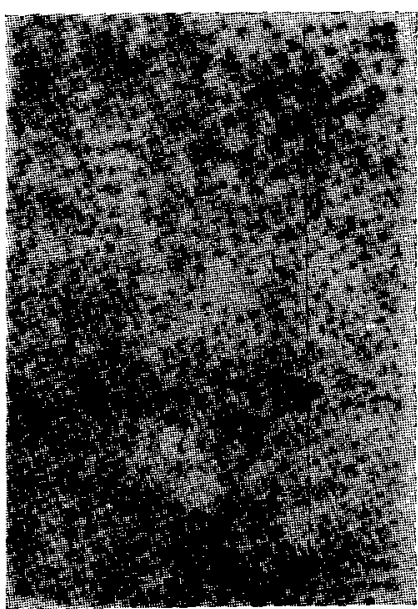

第 5 図 無声放電尤る陰極板上の撒布点 $d=0.9 \mathrm{~mm}, V=10.5 \mathrm{kV}$

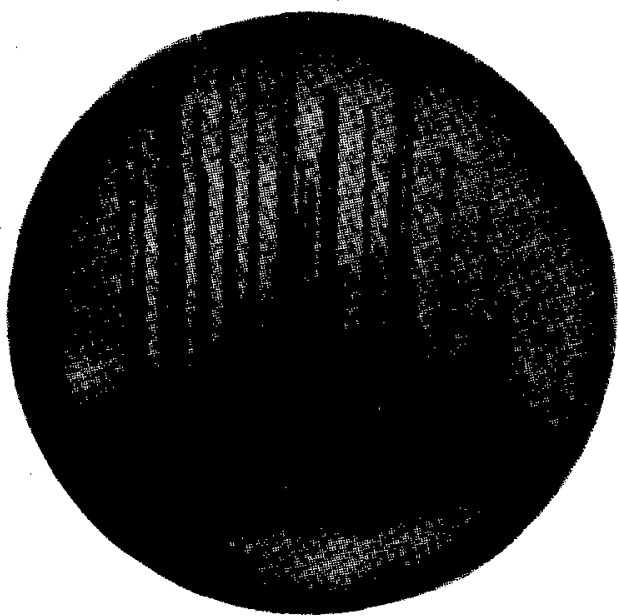

第 6 図第 5 困の放電に対応するオッシログラム $d=0.9 \mathrm{~mm}, V=10.5 \mathrm{kV}$

この高周波電流は第 2 因に示すように，1 2 回の振 動で衰えてしまう振動でめり，従つて荷電量は横の時間 軸と曲線との間で囲まれて部分の面積汇比例する・オッ シログラムの上現われるひげは，とりる直さず第 2 図 の横てつぶれたようなものであるから，ひげの高さは， 第 2 図の曲線の高さとなり，大翼みに考光ても，ひげの 長さ即ち荷電量と考党てるよいのであるが，その上飞前 述のように回路に適当な工夫をして、ひげの長さそのあ のを荷電量に比例するように調整したものである。

第 1 表からる見られるよ 5 亿散布点の数とひげの数と を比較すると, 点の数はひげの 7 倍から 20 倍にも及び その間江全然関係はない.1本のひげは 7 個乃至 20 個の 散布点即ち小放電注対応し，1本のひげ即ち 1 回の衝撃 電流の中には上記の樣な多数の小放電が含まれているこ とがわかる、放電は直流で行わ机ているのであるから，
第 1 表 ひゲの数と散布点との関保

\begin{tabular}{|c|c|c|c|c|}
\hline 放電間吵 & 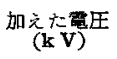 & 警布点 & ひげの総数 & $\begin{array}{l}\text { ひげの長さの } \\
\text { 䌂和 }(\mathbf{m m})\end{array}$ \\
\hline \multirow{6}{*}{0.5} & 8.0 & 91 & 13 & 123 \\
\hline & 8.0 & 134 & 4 & 143 \\
\hline & 9.0 & 303 & 28 & 444 \\
\hline & 9.0 & 230 & 23 & 366 \\
\hline & 9.0 & 467 & 40 & 766 \\
\hline & 9.5 & 842 & 42 & 1402 \\
\hline \multirow{5}{*}{0.9} & 9.0 & 131 & 27 & 425 \\
\hline & 9.5 & 342 & 42 & 1040 \\
\hline & 10.0 & 477 & 36 & 1752 \\
\hline & 10.5 & 576 & 41 & 2062 \\
\hline & 11.0 & 747 & 48 & 2420 \\
\hline \multirow{5}{*}{1.2} & 9.5 & 87 & 22 & 779 \\
\hline & 10.0 & 104 & 29 & 943 \\
\hline & 10.5 & 174 & 34 & 1499 \\
\hline & 11.0 & 274 & 36 & 2200 \\
\hline & 11.5 & 325 & 34 & 2621 \\
\hline
\end{tabular}

1、用いた放䉓管の種類は多種であるが規則的関係は各管共通である。

2. ひげの長さを表わ方単佁は比较上の任意単位である． $\mathrm{mm}$ に特別の 意味范ない。

全体としては只 1 回の一連放電であつて，その電压は，

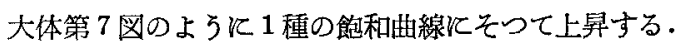
電圧が上り切るまで，即ち飽和值に達する時間は，この 尖験炕括いては回路の時間常数加ら凡 $0.15 \mathrm{sec}$ と算 定される・実際のひげは飽和曲線の肩の近所飞密集して 現われ，従つててれを単掃引のオッシログラムにとると 第7図の上5な形がそのま」オッシログラムに現われ る.ひげは ab 間㑻集して現われるため，これを区別 して観察することは通常のオッシログラムの時間軸の分 解能力では不可能な程度である。1/150 sec の掃引を用 いたのはこれを見易くするためで第 6 図の写真は第 7 図 の1秒間に相当する部分を150倍にのばし，更はそれを 150 飞切つて重悋合せたものと考劣ればよい，従つて第 6 図に括いてはひげが面面全体によくばらまかれ，観察 し易くなつた。一方基線となる直流電圧のオッシログラ

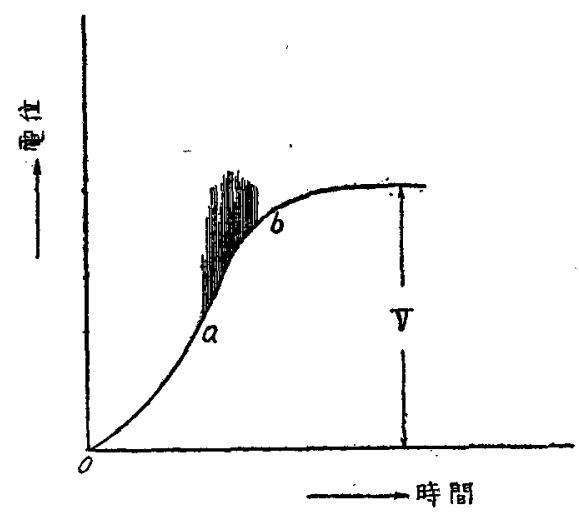

第7図 直流飞上る哭声放電の電圧上界曲線 (ひげは履の部分で起る) 
ムは，雺から最高飽和值までの值が順次同一画面に綝返 し掃引されるので, 結局第 7 図のVの鬲さが基線の幅と なつて現われる。そのため画面の基線は相当太いるのに なつている.この事実は後にひげの長さの和を求める時 飞，或不明の長さの定数值が加わる事となるが，これは いずれの場合にす加算される定数值であるから，考え方 全般の上には差支光とはならない.

電圧の值が第 7 図の ab そそつて上昇し或值に達する と極板上のいくつかの個所で小さい放電が起り，これは オッシログラムの上では1本のひげとして記録される。

これを第 1 次の放電群とする．第 1 次の放電群によつ て, 陰極の表面からは電子が放出し，その結果電極面注 すぐ接する空間部分の電位傾度が下る.これにはいくつ かの原因が考えられるが，大きなるのとして二つ挙げる 事が出来る、第 1 は陰極面の或場所から電子が飛出す と, その部分では当然㓌極面上の電子の量が減る、極の 表面にはいわゆる沿面抵抗があるが, とに角, 或程度の 伝導度を有しているから，放電個所の附近から電子の減 つた放電個所へ電子を補う流れが起る。更に又硝子图は 离抵抗の尊体であるから，背面からも電子は補充されて 来るが，高抵抗のため電子の補充には或時間を要する。

とれ等はいずれる放電の僢閒, 表面のあちこちで一時的 に電子密度を下げる傾向となり，電極表面に直らに接す る空間部分の電位傾度を弱める事となる・次㑗出され た電子は，陽極们つて移動する. この際 $X / p \sim 200$ ， この奏験の行われた条件では $X$ (電位/空間間隙) = $14,000 / 0.1=1.4 \times 10^{5} \mathrm{~V} / \mathrm{cm}, p$ (気体圧力) $\sim 760 \mathrm{mmHg}$ と括いた・Xは間陹の間で一様に抢ちてはいないである らが，一応簡单のためにそらした。電子の移動度に関す る実測は ${ }^{(5)}$ 空気, 酸素等に括いて $X / p \sim 20$ 位の所まで しか得られていないが，ごく大ざつマ゚に考えて，ここに 述べた実験条件の下では電子の進行速度は $10^{-2} \mathrm{~cm} / \mathrm{sec}$ 程度之見積る事ができる. 第 1 次の放電群から第 2 次の 放電群までの間の時間は $10^{-3} \mathrm{sec} の$ 程度であるから，電 子がその間に進さ距離は $10^{-5} \sim 10^{-6} \mathrm{~cm}$ の程度で(5) つて, との值は大体 1 気压に打空気分子の平均自由 行程 $\left(\sim 3.10^{-6} \mathrm{~cm}\right)$ 飞費される時間に注等しい，以 上の状況を総合して, 第 1 次の放電群から第 2 次の放電 群の起るまでの間に，或間隔がある事が了解せられる。 即ち第 1 放電の起つた瞬間, 電極面に荷電の平均化が起 り，これが䉓極面上の電位傾度を減少せしめること，及 び電子の一様の射出によつて，一瞬電極面がごく僅かな がら空間内に押進められたかのような状熋上なり，これ 䉓極面の電位傾度る゙らすように作用するため，放電 壮一瞬停止するのである。しかし，この電位傾度を減ら すような原因惚ち消失して，第1放電と同じような状 況で第 2 放霸が起る.このような現象は順を追つて繰返 されそれがオッシログラムの上の多数のひげとなつて
見られるのである。

各ひげに相当する散布点の数は各回暴り，各衝撃電流 毎に，つまりひげの1本毎に，電極面上に掠いてそれま でに放電しなかつた新しい点に括いて放電が行われる. 換言すると第 1 放電で電極上のいくつかの点が放電し， 第 2 放電では第 1 放電の時の電位の值では放電し得なか つた点, 即ち放電を起すに第 1 放電の時の電位上り, より高い電位を必要とするような，いくつかの点が放電 し，第 3 放電では第 2 放電より更高電位で放電する ような点が放電する・かくして与えられた最高電位まで の值で，放電し得るすへてての点が，放電し終り，全部の 放電点が写真乾板上に現われた事となる.今までの説明 で，第 5 図の一つ一つの点に対応する小放電を放電とい い,これがいくつか集つて，衝撃電流となり，第6 図の ひげとなつたるのを衝撃電流といりて，区别してあるこ とに注意寸る。

さきに述へたようにひげの長さは電極面から放出さ

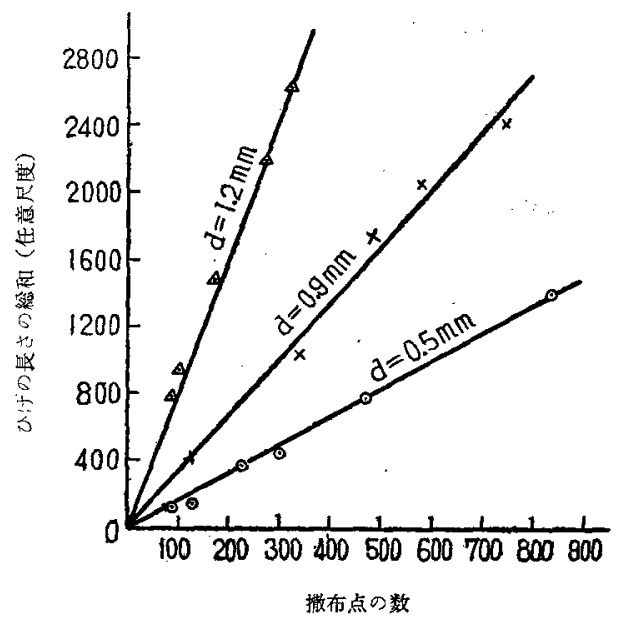

第 8 図ひげの長さの総和即ら全放電に運ぼ れた荷電量と撒布点の総数との関係

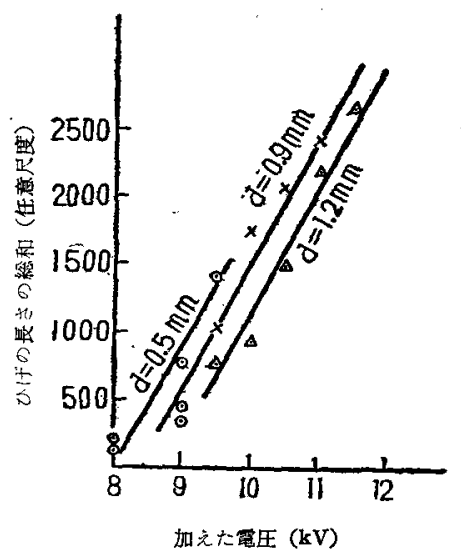

第 9 図放電間隙に加えた電在々 ひげの長さの総和の関係 
れた荷電量に比例するから、ひげの長さの総和は電極面 から放出された荷電の全量を表わす。このひげの長さの 総和は第 $8 ， 9$ 図に示すよ 3 K，加兑た電庄及び，散布 点の総数と直線的関係を示している.ひげの長さの総和 が電圧に比例するととは，同時潵布点の総数も電圧に 比例することをる示し，或電圧以上では，散布点の数は

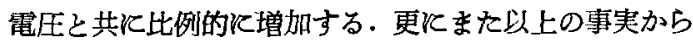
い方ることは散布点の各 1 個あたりの放出電荷量が一定 であり，その一定値は電圧に比例して大きくなる．散布 点は写真で見てわ分るように一つ一つの点の大さは大体

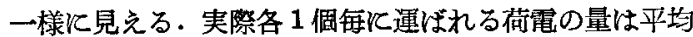
して皆等しく，且つ一般に電压の增加と共にその大いさ も増すことが全実験例てついて見られている。この実験

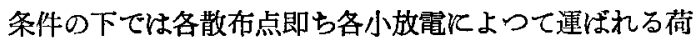
電量は，0.3 1.0 $10^{-9}$ coul と計算されている。 電子 1 個あたり 生成せられるオゾンの分子数は，実験 条件で異るが約数十個である。

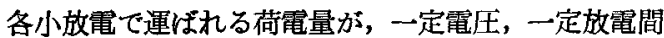
吵で一定值を有するという事は注目すへき事実である. 即ち散布点とひげの実測数の表から分るように 1 回の実 験江現われる散布点の数は，少いるのでも100 亿近く， 大きいるのは 1000 K近い。これらの点で起る小放電が 悉く皆，殆んど同一の電気量を放出しているのである. この理由については理論不明の点もあり，更に進えだ研 究を必要とするであるう。

第 8 図《示されるように，散布点とひげの長さの総和 を示す直線の傾きは，放電間係により異り，間陣の大き くなる程傾きは大きい，即ら間隙が大きくなる程，小放 電 1 個当り運ばれる荷電量は大きくなる。これに関する 実験例は多くはないが，大体の傾向として間渻と放電さ れた荷電量の 2 乗とが，ほ上゙原点を過る直線で示され る.荷電量の 2 乗は加えられたエネルギーに関連すると 考えられるから，加えられたエネルギー量が，放雷間際 と直線的変ることとなる。この事は本報 I の(1) 式 を導き出した考兄方以る矛盾せず，首肯し得るすのと考 亮られる。

第6図の説明及びその前段で説明したようにひげによ つて示される荇撃電流，即らひげを構成する小放電群炕 よつて運ばれる電流は一種の高周波電流である.どうし てか」る電気振動が起るかという理由については，実験 的な証拠を以て解明する段階恎つていないが，前段 飞於て放電が閭歇的に起る理由として挙沃た理由は，い ずれる渾ばれる荷電が振動的なるのとなる事を示唆して いる. 電極表面のいくつかの小点で電子が射出され，こ れをうめ上うとしてその周囲乃至極の背面から流れ込む 電于の群は, その抵抗, 回路のるついくつかの容量, 及 び白己感応等によつて振動電流を形成する.上述の諸元 から時間定数を算定して求めた振動数は少く子定性的に
は筋の通つた值を示している．更に又電子が空間に射出 されごく短い距離を走つた後散乱されてしまう現象は 一つの衡撃電流であり，艺の衝撃電流はいくつのフーリ 工級数の合成として表わし得る筈である.これらの合成 成分はそれぞれが一つの振動であり，従つて衝撃電流は 非常に多くの振動成分の合成であらう事は容易に想像せ られる。無声放電化伴つて起る高周波電流の周没数分析 についてはいくつかの報告があるがこれ等の結果を総合 してみよう。

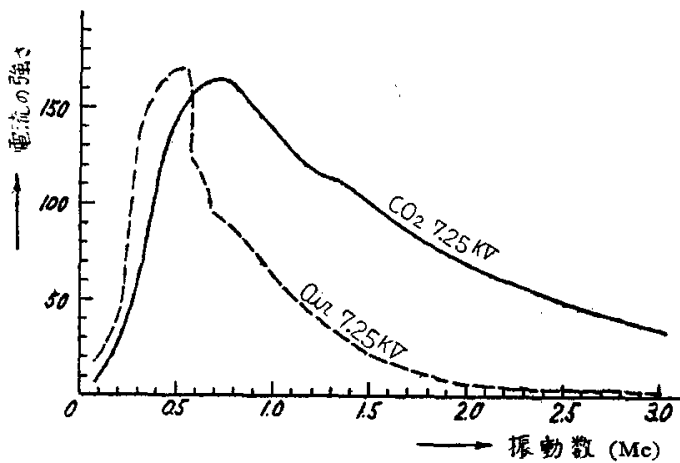

\section{振 動 数 $\mathrm{Mc}$ 気体圧力 1 気压 放電電圧 $7.25 \mathrm{kV}$ 電流の強度 任意尺度 放電閣隙 $1 \mathrm{~mm}$ \\ 第 10 四空気及び炭酸ガス中の無声放電に 招ける高周波電流の周波数分布}

平板型放電管を用い，1気压の空気及び炭酸ガスを用 いて測定した結果 ${ }^{(6)}$ が第 10 図である. 測定回路には二 重へテロダイン型を用い，周波数 $70 \mathrm{kc}$ 3 Mc までの区 間を殆んぞ一様な感度て測定し得るるのを使用乙てい る.この図で見られるょうに，空気については約 $500 \mathrm{kc}$ 附近に振動数の極大值があり，炭酸ガスについては 700 $\mathrm{kc}$ 附近火極大值がある.放電管の間橸, 放電々压の值が 変つても，この極大の位置はあまり変らない，津明(7)及 その共同研究者たちは, 水素, 酸素, 空素, 空気等们 いて種々の条件の下放電を行わしめ，発振電波の周波 数分布について広、範囲の研究を行つている.第11図 はそれ等の測定の中から例をとつたるので，前の鈴木， 内藤の測定した周波数より遙低低い周波数带域をで測定 を㹡げている。第 11 図は空気中の無声放電に和ける周 波数分布の例で極大の位置及び高い周波数部分における 曲線の様于は，鈴木，内藤の得た結果とよい一致を示し ている. $20 \mathrm{kc}$ 以下の部分の振動電流は，今まで述べて 来た種類の振動電流とは本質的に異るもので, 衝撃電流 の発生数がこの振動数に近いことから，むしろそれにる 或関係をもつているものと考光られるが,てこの測定の重 点でないので今はこれには触れない。

第 12 図 ${ }^{(7)}$ 亿於ては，水素中の無声放電に怙ける高周 波電流の周波数分布が，電圧と共江変る有様を示してい 


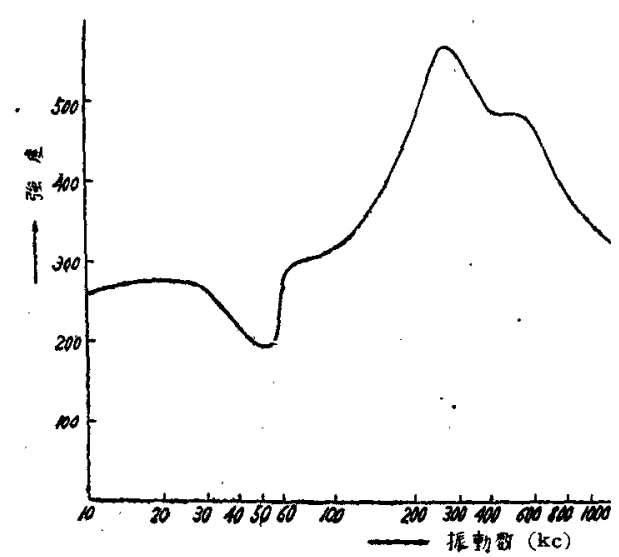

第11图 空気の中の無声放電に敊ける 高周波電流の周波数分布

放電間隙 $1.5 \mathrm{~mm}$ 放電々正 $21 \mathrm{kV}$

気体王力 1 気质電流强度 任意风度

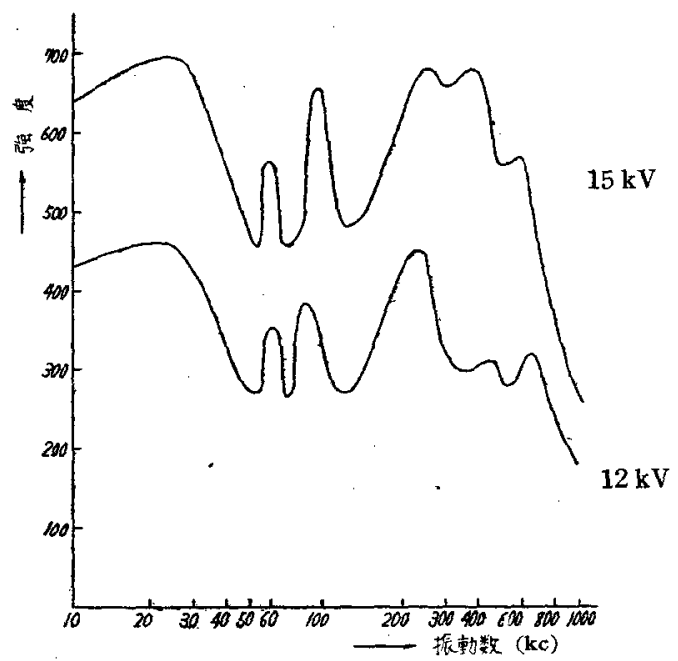

第 12 図周波数分布に项任寸電圧の影響

気体 水素 流速 100 cc/min

気生 1 気生 放電開始電压 $\sim 10 \mathrm{kV}$

る、電圧が上れば，高周波電流は全般的に大きくなるの みならず，周波数曲線の極大の位置る変る。この事は周 波数の分布が回路の時間定数のみに支配されないことを 示している.更に同じ著者等の他の奏験によれば周波数 曲線の有様は, 気体の種類 (酸素, 水素, 咥素, 空気 等)，之の圧力, 水蒸気の含有度，混合気体を用いた場 合の混合の割合等, 全く放電間吵部のみの条件を変える 事によつて, 衝撃電流のオッシログラムの様相, 周波数 分布曲線等が，いずれの場合にる著しく変ることを観察 している.このことは前述の通り周波数分布の有様が気 相の性質によつて左右される事の証左であつて，高周波 発振の機構の中で, 気相中に括ける電子走行の有様に大 きな役割を演じている事が知られる。即ち放電空間中を
晹極儿问つて殺到する電子雪崩の爆発的分歧が，全般的 な衙撃電流を形成し，これを組成するフーリ工振動成分 が周波数分布のスペタトルとして現われるるのと解积し てよいであろう.しかしこの高周流発振の機構について は，まだ末知の部分を多く残し，今後の研究にまたねば なら点の多いことは，前に述べた通りである。

無声放電のさいに起る衝撃電流，即ちひげの本数につ いて，本稿 351 頁行に述べたように，放電管等を通して 荷電が補充される事を前提として，ひげの数を計算で求 める試みがある(8). 即ち第 1 次の放電群, 即ち最初のひ げの起るまでの時間及びその放電々压を，実験条件下に 括ける回路定数, 放電開始電圧, その他の条件を基とし て算出する. 更住第 1 のひげを基点として，同様の計算 によつて第 2 のひげのおきるまでの時間を求める.順次 このようにして，加壳られた電圧が悉く放電によつて消 費しつくされるまでに起るひげの本数 $n$ を計算によつて 求める事が出来る. 彼等は鈴木, 内藤の実験条件 ${ }^{(4)}$ に大 石の火花電压及び放電消滅電圧飞関する式(9)を用いて計 算した結果を，奏测結果と比較したところ，相当に淽足 すべき結論を得た. 向この計算によつて值流放電 ${ }^{(4)}$ の場 合得られるひげの数が，予期されるよりも羊かに多いこ とも説明せられる。

䏌上述の火花電圧及び，放電開始電王については，多 くの研究があるが，無声放電とのるのについて測定值は 甚だ少い，藤及びその共同研究者 ${ }^{(10)}$ たちの研究によれ ば，火花開始電压は金属間踩の場合と，無声放電の場合 とは，あまりその值を異にしていない，しかし無声放電 の場合に和ける臨界電位傾度は, 金属間隚の場合に比較 して極めて高い(第 13 図).下の曲線群は金属間隙の場 合の值で，上の曲線群は無声放電の場合である。無声放

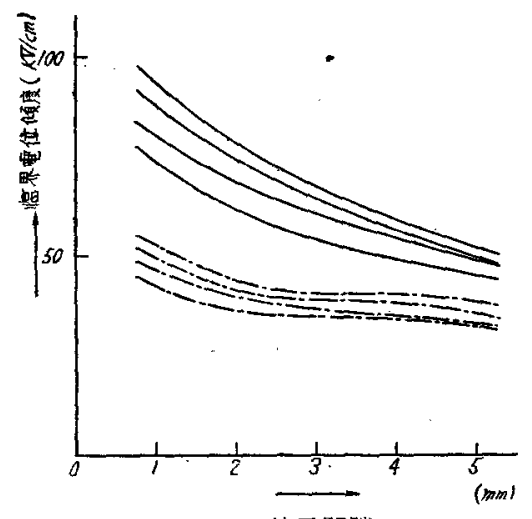

放電間陪

第 13 図 臨界電位傾度と放電間隙との関係

上の実線は無声放電，下の鋇線注金属電極に関

するものである・無声放電の曲楾群については

上から，炭酸ガス，窒素，空気，酸素を示し，

下の金風電極の曲線群については上から䓨素, 空気，炭酸ガス，酸素を表わす。 


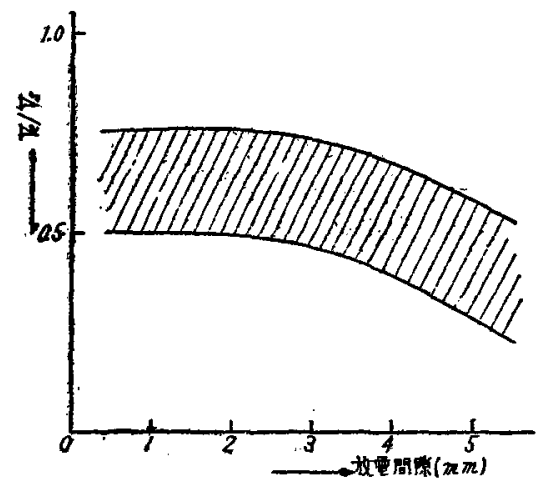

第 14 区 無声放電に枋いて 消喴電圧/ 火花電王と故電間隙との関係

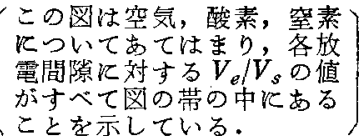

\section{電の場合の高い值は}

$E($ 臨界電位㑯度 $)=\left[V_{s}(\right.$ 放電開始電圧 $)+V_{e}($ 放電 消滅電庄) $] / d$ (放電間陌)

なる式の第 2 項即ち消滅電圧の値が高い為である。

な挌， $V_{e} / V_{s}$ は間陸隹よつて多少異る值を有し，その 関係は第 14 図示されているようK, 間幥の小さい間 は大体一定であるが，大きくなると共炕少しその值が小 さくなる傾向がある。

以上述へたように，無声放電の電流の中，振動数の最 る高い振動電流恃化学反応汇或影響をるつていると共
に，その発振機構る空間的な要素を有していることが 5 かがかれるが，末だ解明せられない部分も又決して少く ないのが, この方面の研究の現状である.

(昭 31-7-4 受理)

文献

(1) 鈴木：㫣化 (this Journal) 24, 207 (1956)

(2) M.Suzuki : Proc. Jap. Acad., 26, 20 (1950)

(3) E. Briner,B. Susz: Helv. Chim. Acta.,14, $594(1931) ; J$. Chim. Phys., 28, 206 (1931); Helv. Chim. Acta, 18, 1468 (1935): A.A. Balandin, J.T. Eidus, N.G. Zalogin: Compt. rend., URSS. 4, 132 (1934); E. Briner, Ch.H. Wakker, B. Siegrist: Helv. Chim. Acta, 19, 287 (1936); E. Briner, H. Wakker, H. Paillard, G. Carrison, Helv. Chim. Acta., 19, 308 (1936); A. A.Balandin, J.T. Eidus, N.G. Zalogin : Acta Physicochim., 4, 365(1936); J.T. Eidus : Bull. Acad. Sci. URSS. 737(1938); E. Briner,J. Desbaillets, F. Richard H. Paillard: Helv. Chim. Acta., 22, 1096 (1939); E. Briner, H. Hoefer: ibid., 23, 800, 826 (1940); A.A. Balandin, J.T. Eidus, E.M. Terentjeva: Compt. rend, UTRSS, 27, 343 (1940); E. Briner, H. Hoefer: Helv. Chim. Acta, 24, 96(1941); J. E. Nyrop: Dan. Pat. 63297, March, 26 (1945); E. Briner, J.J. Kundig, R. Tolun: Helv. Chim. Acta, 28, 714 (1945); E. Briner, H. Hoefer, J.J. Kundig: Helv. Chim. Acta, 30, 105 (1947) ; W.L. Harris, A. von Engel : Proc. Roy. Soc., (London) B. 64, 916 (1951).

(4) M. Suzuki, Y. Naito : Proc. Jap. Acad.,28, 469 (1952)

(5) R.A. Nielson, N.E. Bradbury: Phys. Rev., 49, 338. (1936); R.A. Nielson, .E. N Bradbury: Phys. Rev., 51. 69 (1937).

（6）鈴木, 肉藤：放電化学誌， 2 (1) $27 ，(1954)$

(7) 津田, 恢藤, 㘿原：放電化学誌：2. (2) 18，29 (1954)

(8) K. Honda, Y. Naito: J. Phys. Soc. Jap., 1007 (1955)

(9) 犬石; 電気工学論交集, 2, 13 (1950)

(10) 藤, 竹村, 多田: 放霆化学琵, 2, (2) 18 (1954)
$\S$ ソ集本年度上半期の工業生産実綕 ソ逨閣僚会議 中央統計局は 1956 年 (第6 次 5 力年阡画初年度) 上半 期の国家計画遂行実績を次のよ5亿発表した。

工業全体の生産計画 遂行率は $102 \%$, 総生産高は 55 年度より $12 \%$ 增加した。部門別遂行率 (\%) 次の通り。 製鉄 98, 非鉄金属 103, 石炭 98, 石油 101, 化学工業 102, 発電所 103 ，電気技術工業 103 , 無線工業 102 , 重機 104, 工作機械, 器具 99 , 運輸機械 104 , 自動車工 業 102, トラクター, 農機 101 , 土建機械 103 , 建材 97 ，製紙 99.5 , 軽工業 102 , 食品工業 105 , 漁業 98 , 肉乳工業 108. 主要物資の生産高（単位 $\mathrm{t}$, カッコ内は

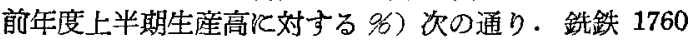
万 (109), 銅鉄 2400 万 (108), 圧延銅 1870 万 (107), コークス 2290 万 (107), 石炭 2 億 900 万(110), 石油 3970 万 (119), ガス 64 億 $\mathbf{m}^{3}$ (127), 雷力 940 億 $\mathrm{kWh}(114)=$ 内水力 130 億 3000 万 $\mathrm{kWh}(111)$ ，鉱物肥 料 540 万 (115), 苛性ソーダ 37,000 (113), 電気発動 機 82 万 4000 台 (109), 貨物自動車 17 万 6100 台 (109), 乗用車 46,500 台 (92), バス 4400 台 (108), セメント 1160 万 (106), レンガ 90 億個 (108), 綿織 物 28 億 $\mathrm{m}$ (95), 毛織物 1 億 2900 万 m (107), 麻
織物 1 億 8900 万 . m. (124), 絧織物 3 億 7400 万 $\mathrm{m}(?)$ カメラ 55 万 2000 台 (112), ラジオ, テレビ 210 万 台 (112)，ミシン 91 万 3000 台 (?)，オートバイ 14 万 1000 台 (120), 自転車 160 万台 (114), 紙? (108) 食肉, 肉加工品 56 万 (119), 魚肉 140 万 (106), パ ター 760 万 (138).

（毎日，昭 31.8.3）

$\S$ 印度の肥料增埕計画 印度活いて第 2 次 5 力年 計画の末期《括ける肥料の需要增は Sindri 工場の $60 \%$ 搪張と新しく Nangal, Rourkela, Neyveli 03 肥料工 場の設立によつて完全に充たされるすのと考えられる。 Sindri 工場の拡張計画は尿素日蓙 $70 \mathrm{t}$, 硫安日産 $400 \mathrm{t}$ となるのであるがこれは既湊行されつつある．経費は 100 百万 Rs 以上との推定で, 月計画は 1957 年末には 完成する筈で，その時は Sindri のコークス炣ガスの全 生㢈がこの目的使用されるととになろろ. Nangal 肥 料工場江経費 220 百万. Rs で, 年産硝安 200,000 t, 重 水 $7.5 \mathrm{t}$ 生産, 1959-60 年飞生産開始の予定であり, 約 $160,000 \mathrm{~kW}$ の電力を要する見込みである.他の 2 工場はそれぞれ窒素年産 $80,000 \mathrm{t}$ 扔よび $70,000 \mathrm{t}$ 生産 で严炭計画の一部として建設されることになつている。 [C.T.J., 138, 943 (1956)] (J.K) 